\title{
Liquidity: Water and Investment in Mandate Palestine
}

\author{
Cristina Violante
}

In this article, I illustrate two ways in which Zionist settlers appropriated water in Mandate Palestine. The first way was through the imposition of a new kind of property regime, one that measured and defined water rights in terms of volume. This differed from customary Palestinian practice, which distributed water in time-based shares. I argue that volume-based measures made water more easily bought and sold and, by extension, more like a commodity. The second method of appropriation I detail is the granting of concessions to generate hydroelectricity to the Palestine Electric Corporation. These concessions gave the company control over three of Palestine's major rivers, which it then turned into an object of investment for foreign shareholders. As a result, water use cannot be understood separately from electricity during the Mandate. While these two processes might appear unrelated, I argue that they were both legalized methods of exclusion that, when taken together, reveal a larger process of gradual, albeit incomplete, dispossession of water resources. While Zionist settler colonialism legitimated itself by claiming to efficiently use natural resources, such as water, in actuality, it sustained itself by imposing exclusive property rights.

\section{INTRODUCTION}

There is a saying in the village of Battir, located to the southwest of Jerusalem, that a week "lasts eight days, not seven." Each of Battir's eight families has a one-day long claim to the village's water supply. One family uses its share-a day's worth of waterand then passes it to the next family, meaning that a full rotation of water lasts eight days (Trottier 1999; Kershner 2012). For those accustomed to thinking of water usage in terms of a given volume of water, this time-based measurement may appear strange. What does it mean to possess a claim to one day of water? Why conceive of one's rights to water in terms of time as opposed to volume? This time-volume distinction, and the contrasting regimes of property rights in which it is embedded, lies at the heart of this article.

In this article, I examine some of the processes by which Zionist settlers dispossessed Palestinians of their water resources over the course of the British Mandate, which spanned from the early 1920s to the creation of the State of Israel in 1948. Zionist appropriation of water was neither as organized nor as systematic as that of land. It occurred in both direct and indirect ways. This article examines two such ways in

Cristina Violante is a $\mathrm{PhD}$ Student in Jurisprudence and Social Policy, University of California, Berkeley; JD Student, Berkeley Law, Berkeley, CA, United States. E-mail: cviolante@berkeley.edu

The author thanks Timothy Mitchell, Nadia Abu El-Haj, Christopher Tomlins, Owain Lawson, Jonathan Simon, Griffin Brunk, Sherene Seikaly, Ronen Shamir, and Vivek Yadav. 
particular, with the hopes of revealing something not only about the Zionist project and Palestinian dispossession but also about settler colonial processes at large. While settler colonialism often understands and justifies itself in terms of efficiency and progress, I argue that, in this instance, it actually functioned through legalized processes of exclusion.

First, I present a basic overview of the customary law of time-based water sharing-a practice seen across much of the larger Arab and Islamic world. I argue that this time-based method of water distribution can be understood as a system of rules that govern how a given community shares its water resource. Recognizing this set of rules as an institution in its own right is important. Doing so enables us to contrast it with volume-based measures, which were the preferred unit of incoming settlers and the British. I show that, with time-based water sharing, water rights are embedded in a larger network of social relationships. Volume-based rights, on the other hand, abstract away from the larger social milieu in which water use is embedded, making them better suited for a settler colonial context, in which a newcomer seeks to buy up or invest in water. I argue that volume-based measures facilitated a process of commodification, making water an object of speculation over the course of the Mandate.

The shift from time- to volume-based measurement, and the process of commodification that it facilitated, in turn helped pave the way for a more direct form of Zionist appropriation of water resources. I show how the corporate form itself-in this case, that of the Palestine Electric Corporation (PEC)—was used as a tool of exclusion. The PEC held monopolistic rights to generate hydroelectricity in northern Palestine and Transjordan and was purposefully organized in such a way as to ensure Zionist control over these means of production. At the same time, it funneled foreign capital into Palestine, making its rivers an object of investment for foreign shareholders, and amassing enough capital to be able to assert a kind of de facto sovereignty. While Zionist state building during this period is often framed as a socialist or quasi-socialist endeavor, examining the PEC shows that there were key capitalist components to the statebuilding process.

Building on current scholarship on the PEC, I show how it restricted the possibilities for water use in an area that had historically been primarily agrarian. The concessions that the company operated to generate electricity gave it control over northern Palestine's three major rivers, control that the corporation exploited to the fullest. It is for this reason that water use during the Mandate cannot be understood separately from that of electricity. The PEC effectively cut off these rivers from local use, to the detriment of Palestinian and Zionist farmers alike. When the history of the PEC is seen in terms of the shifting regimes of property rights over water, it shows how water appropriation worked in intimate and local ways as well as from afar. While the very basics of how water was measured were gradually redefined, this water also became an object for foreigners to invest in and control. This article suggests that these two processes might not be as distinct from one another as it appears at first glance. Taken together, they show how a conceptual transformation-a shift in the ways of measuring water-helped pave the way for the dispossession of one of Palestine's most valuable resources. 


\section{“ABSORPTIVE CAPACITY” AND INTENSIVE AGRICULTURE}

Following the First World War, the needs of the British government and the Zionist movement converged in important ways (Wolfe 2012). The Covenant of the League of Nations divided up the former Ottoman Empire and placed it under the mandate system, a type of transitional protectorate that put areas "inhabited by peoples not yet able to stand by themselves" under the tutelage of more "advanced nations." Palestine and Transjordan fell under British authority. Yet British duties to Palestinians were in tension with the Balfour Declaration, a 1917 British statement in support of building a "national home for the Jewish people" in Palestine. ${ }^{2}$ The Palestine Mandate, which was ratified in 1922, reiterated support for such a Jewish home. ${ }^{3}$ The British government thus had to find a way to make good on the Balfour Declaration and supposedly not compromise their colonial duty as the caretakers of the preexisting population.

This purported balancing of Zionist and Palestinian interests was accomplished, at least in theory, through the metric of "absorptive capacity." The concept was borne out of a 1922 British white paper that said that Jewish immigration quotas would be calculated based on "the economic capacity of the country at the time to absorb new arrivals." Absorptive capacity was determined in part by a Malthusian calculation of the potential of Palestine's natural resources, such as land and water, to hold and employ people. Tying Jewish immigration to absorptive capacity meant that throughout the Mandate there was an emphasis on surveying Palestine and creating statistical knowledge of its economic potential (Seikaly 2016; Sasson and Shamir 2020). ${ }^{5}$

The British saw implementing intensive agriculture in Palestine, a place that historically practiced mostly extensive farming, as a means of enhancing absorptive capacity. This distinction between intensive and extensive land cultivation was based in part on a Lockean understanding of what it means to use land effectively versus letting it go to waste, which, from the British perspective, was precisely what the Palestinians did (Survey of Palestine 1946; Wolfe 2012). Intensive land use meant a more efficient utilization of natural resources-more frequent crop rotation, irrigated farming, and more labor- and capital-intensive work—and, by extension, more densely settled land. According to the British, intensive agriculture could thus provide the

1. Covenant of the League of Nations 1919, 13 AJIL Supp. 128 (1919).

2. Arthur James Balfour to Lord Rothschild, "Balfour Declaration," November 2, 1917, reprinted in Yale Law School: The Avalon Project: Documents in Law, History and Diplomacy, https://avalon.law.yale.edu/ 20th_century/balfour.asp.

3. The two key legal documents that constituted the rules of the Mandate- the League of Nations Mandate for Palestine and the Palestine Order-in-Council-began to be drafted in 1919 and were published in 1922. See "The Palestine Mandate," reprinted in Yale Law School: The Avalon Project: Documents in Law, History and Diplomacy, https://avalon.law.yale.edu/20th_century/palmanda.asp; see also "The Palestine Order in Council," August 10, 1922, https://unispal.un.org/UNISPAL.NSF/ O/C7AAE196F41AA055052565F50054E656.

4. "British White Paper," June 1922, reprinted in Yale Law School: The Avalon Project: Documents in Law, History and Diplomacy, https://avalon.law.yale.edu/20th_century/brwh1922.asp.

5. Sherene Seikaly (2016) has shown that this emphasis on measuring was part of a larger trend, in which colonial powers attempted to configure the Middle East as a coherent economic unit. Timothy Mitchell $(2002,82)$ has similarly described a culture of "calculability" as characterizing contemporary colonial policy in the region. 
economic basis to accommodate an incoming Jewish population without compromising the livelihood of the Palestinians (Shafir 1989). British policy thus explicitly promoted intensive farming as the basis of Zionist colonization. The 1922 Palestine Mandate stipulated that the British administration "shall encourage ... close settlement by Jews on the land," a reference to the use of intensive agriculture. ${ }^{6}$ Despite minimal British funding for local education and social services over the course of the Mandate (Seikaly 2016; Wolfe 2012), the colonial government invested heavily in, and assisted the Jewish Agency with, agricultural research (Survey of Palestine 1946).

Intensive agriculture also filled a major need for the Zionist movement-a viable economic program. By the beginning of the First World War, the Zionist movement was still struggling to establish a self-sustaining economic basis for settlement in Palestine. During the first aliya, or wave of Zionist immigration from 1882 to 1903, settlements were primarily engaged in monocultural cash crops for export, such as viticulture and citrus growing. This was difficult to sustain on unirrigated land and uncompetitive in international markets. During the second aliya, from 1904 to 1914 , there was a shift toward mixed farming, but Jewish farmers were again unable to sustain themselves along these lines, prompting many who immigrated at this time to eventually leave Palestine altogether. The eventual answer was the kibbutz, a Jewish-only communal farm that practiced intensive agriculture. With the support of Zionist institutions and overseas capital, the kibbutzim were shielded from market imperatives. They thus provided an economic life for Jewish immigrants that would have been much more precarious if there had been a need to yield a profit, and, in doing so, they helped create a foundation for the eventual state (Shafir 1989; Wolfe 2012).

Yet, over the course of the Mandate, the Zionist perspective also came to see absorptive capacity as a malleable metric. In 1936, David Horowitz, director of the Economic Department of the Jewish Agency, noted in his report "Scheme for the Settlement of German Jews in Palestine," that

a country's absorptive capacity is not an absolute category. The limits of absorption are no longer determined only by the... factors of geographical conditions and natural resources, but by the variable forces of scientific technique and political manipulation. With the aid of science and politics absorption has become an elastic concept capable of considerable expansion. ${ }^{7}$

Science and politics thus became the means of expanding absorptive capacity, of which scientific, irrigated agriculture and the development of water resources became integral parts (Reichman Katz and Paz 1997). According to the Jewish National Fund and the Jewish Agency for Palestine Water Research Bureau, absorptive capacity would

6. For later policy examples, see M. T. Dawe, "Annual Report of the Department of Agriculture and Forests for the Year Ending March 1934,” 1934, CO 733/273/6, The National Archives (TNA), London, United Kingdom; Commissioner for Migration \& Statistics and the Government Statistician, "Some Notes on the 'Economic Considerations' and Some Practical Aspects of 'Absorptive Capacity'," 1937, CO 733/ 346/14, TNA.

7. "Scheme for the Settlement of German Jews in Palestine," S25/9707, Central Zionist Archives, (CZA), Jerusalem, Israel. 
"inevitably depend on the intensive exploitation of water resources." ${ }^{8}$ For this reason, Zionist entities expended a significant amount of resources on gathering hydrological knowledge of Palestine and developing water infrastructure (Shamir 2013, 2017; Sasson and Shamir 2020). It is in this context that water became crucial to the project of creating an economy that could sustain Zionist settlement and growth. As is clear from the concept of absorptive capacity, water management was more than just an issue for engineering; it was also a political cause. Water supply thus became the site of considerable debate, a great deal of which concerned the very basis of how water rights were measured and defined.

\section{“A MULTIPLICITY OF UNITS”}

Current scholarship on water in Mandate Palestine typically references the Ottoman Civil Code, Mejelle, in discussions of preexisting legal regimes. Yet the Mejelle was relatively recent in implementation and neither reflected actual practice on the ground (Survey of Palestine 1946; Nadan 2006) nor fully represented Indigenous legal institutions of water sharing (Schorr 2014). While a deeper analysis of Palestinian water rights during the Mandate still remains to be undertaken, we can begin in this direction by presenting a simplified overview of time-based water sharing. ${ }^{9}$ Contemporary British accounts are littered with references to such sharing, but they, and scholars since then, have not entirely recognized such references as pointing toward a coherent system. ${ }^{10}$ While time-based distribution worked differently from place to place, varying from one water source to the next, its local and customary nature does not mean that it was random or that it did not comprise a system. Recognizing it as such helps shed new light on how we understand water appropriation during this period.

Scholars have documented two basic schemas of time-based water distribution around the Arab and Islamic world, including in the Levant or greater Syria. In one such scheme, water is tied to the land itself and cannot be alienated separately from the land it irrigates. Water is divided proportionally according to the amount of land to be irrigated. In the second system, water rights can be sold off or rented separately from the land they accompany and are typically measured as time-based turns in a

8. Jewish National Fund and Jewish Agency for Palestine Water Research Bureau, "Water Survey of Palestine," 1942, KKL8/66, CZA.

9. I hesitate to call time-based water sharing either Arab or Islamic. While the practice spread to areas such as Islamic Iberia (Glick 1970), which would be strange to call Arab, it is also unlikely to be an institution that originates ex nihilo in Islam (Attia 1985). Given that time-based water distribution is reported in Roman accounts such as those of Pliny the Elder (qtd. in Attia 1985) and in the Digest of Justinian, it is likely a pre-Islamic practice. The goal of this article is not to present time-based water distribution as a reified, age-old institution but, rather, to highlight the fact that it is a practice that helps us understand something more about water appropriation during this period.

10. Consider, for example, that A Survey of Palestine (1946, 390), carried out by the British government in December 1945 and January 1946, refers to "selling, leasing and pledging astronomical fractions" of water for irrigation. While it is, of course, possible that "astronomical" in this context simply means very large, I think it is much more likely that this refers to the use of astrological markers- the movement of stars and planets-to delineate time shares (Attia 1985). Such an interpretation is reinforced by the fact that, later in the same paragraph, the survey bemoans the lack of legislation that would allow the government to "draw up a roster of turns" (390). Yet the British understood the astronomical shares as part of "the Muslim law of inheritance," not as a system of water governance (390). 
rotating system or a "water shift" $(40) .{ }^{11}$ These two systems are not necessarily mutually exclusive. Scholars have documented instances in which the sharing scheme could switch from one system to the other (Hammoudi 1985). Regardless of such specificities, there is a common underlying thread. Claims to water are not conceived of in a form of abstract rights to a definite amount but, rather, as a proportion of the larger whole.

There is evidence from British archival sources that both of these schemas existed in Palestine during the Mandate, but more research is needed to say definitively. A British irrigation advisor, D. G. Harris, wrote in a detailed note in 1935 on a proposed irrigation ordinance:

The Irrigation Officer will make measurements of the volume of water available and of the area of land to which it appertains, while the Water Settlement Officer will record all water rights ... and incorporate them in a Report. This Report will necessarily be based largely on verbal evidence rather than written contract and will probably describe the rights in a multiplicity of units, one man being entitled to a proportion of the discharge of a spring, another to the volume passing through an opening of ascertained size, another to a certain number of hours of supply in a rotation of a certain number of days, and so one [sic]. ${ }^{12}$

This report, not to mention the proposed ordinance itself, never materialized. But it gives us a window into how the British perceived Palestinian water claims and the "multiplicity of units" with which any memorializing of such claims would have to grapple. It is likely that the first unit mentioned- "a proportion of the discharge"-corresponds to the first of the two schema mentioned above-namely, proportional water claims that are tied to the land that they irrigate. The last unit described- "a certain number of hours of supply"-likely correlates with the second schema-namely, water rights that have been alienated from their associated land and are thus understood solely in terms of time as opposed to a proportion.

The British administration did not always understand or appreciate time-based water sharing. Lewis French, the British director of development, wrote in his 1931 report, "Agricultural Development and Land Settlement in Palestine" of Beisan, where users rotated water every twenty to thirty days: "Use of land and water is at present as unsystematic and chaotic as can be conceived ... water channels wander about apparently with no object and no system. Yet they are all subject to well-known rights" (see

11. In the context of the Drā Valley in Morocco, the former is called allām and the latter mulk, but a water source could switch back and forth between the two systems (Hammoudi 1985). Thomas Glick (1970) describes a similar dichotomy in Iberia, where the two systems were more rigid.

12. "Note on Proposed Irrigation Ordinance," February 8, 1935, 20, CO 733/284/3, TNA. Interestingly this report was to be modeled, according to D. G. Harris, on a similar register used in the state of Wyoming. Among numerous measures the British wanted to implement was the standard of "beneficial use," so that one user could not claim rights to more water than he used effectively, similar to the doctrine of prior appropriation in the Western United States. See also "Memorandum Explanatory of the Surface Water Ordinance of 1935," enclosure to a letter from Hall to O. G. R. Williams, December 1935, 13, $\mathrm{CO} 733 / 303 / 6$, TNA. 
also Tyler 2001). ${ }^{13}$ What the British perceived as chaos fed into colonial discourse about the need to civilize native land tenure, water use, and agriculture. ${ }^{14}$ Colonial policy aimed at partitioning communally held land, and the British were continually looking for ways to limit what was often perceived as an inefficient or wasteful use of water, as with the Palestinian farming methods that they found wasteful and primitive (Nadan 2003). ${ }^{15}$ With an incoming settler population, there was a constant push to maximize both water and land use in order to accommodate more people.

In the contrast between time- and volume-based water rights, and the broader legal regimes of which they were a part, we can draw a parallel to Gershon Shafir's (1989, 201) analysis of pre-Mandate Zionist colonization as the "decisive historical encounter" of two different understandings of land ownership. Drawing on Edward Said (1979), he points out that settler colonialism often justified itself by claiming to have superior knowledge of land cultivation and, by extension, of civilization: "Ultimately, even disregard for local custom was not just a matter of ignorance, but the unavoidable opposition of two types of property systems, and at stake was the very legitimacy of European overseas settlement" (Shafir 1989, 202). The British took for granted that their methods of water and land use were superior and this basic sense of superiority justified the larger colonial project.

There are two important differences between time- and volume-based measuresdifferences that explain how water became increasingly commodified. First, while volume is a standardized unit of measurement, time is not. Water flow measured in time is never constant-it varies based on weather and season. During a drought or a dry summer, a spring's output decreases. A volume-based unit, on the other hand, guarantees the same amount of water in each instance it is used. A cubic meter of water is the same from any source, under any weather conditions, during any time of the year. Economic and environmental historians have often emphasized the role of standardized measures in the commodification of natural resources (Kula 1986; Cronon 1991; Worster 2004). Donald Worster $(2004,143)$, for example, has argued that the division of land in the Midwestern United States into neat, 160-acre square parcels for white settlement was a way of making the land fungible: "It was much easier to buy and sell land when it was conveniently laid out in uniform, interchangeable boxes. To further this process of exchange, every parcel became an arithmetical abstraction, a quantity identified by a number." The unit itself-the 160-acre lot-conveyed very little qualitative information about the underlying good. Each lot was, at least in theory, the same as any other. Measuring land in uniform boxes thus abstracted it, dislocating it from its social context and transforming it into a commodity that was more easily bought and sold and on which it was easier to speculate.

Something similar occurred in terms of water during the colonization of Palestine. Like in the western United States, there was an incoming settler population in Palestine

13. "Agricultural Development and Land Settlement in Palestine" ("French Report"), December 23, 1931, 77, CO 733/214/5, TNA.

14. This was not the only kind of local measurements that seemed opaque and irrational to British administrators. Common measures included "the wuqiya, the ratl, and the kayl," which varied in size from one locale to the next (Seikaly 2016, 94). Similarly, farmers in northern Palestine typically measured their annual crop load in terms of a "camel load of hay" (161).

15. "Memorandum Explanatory." 


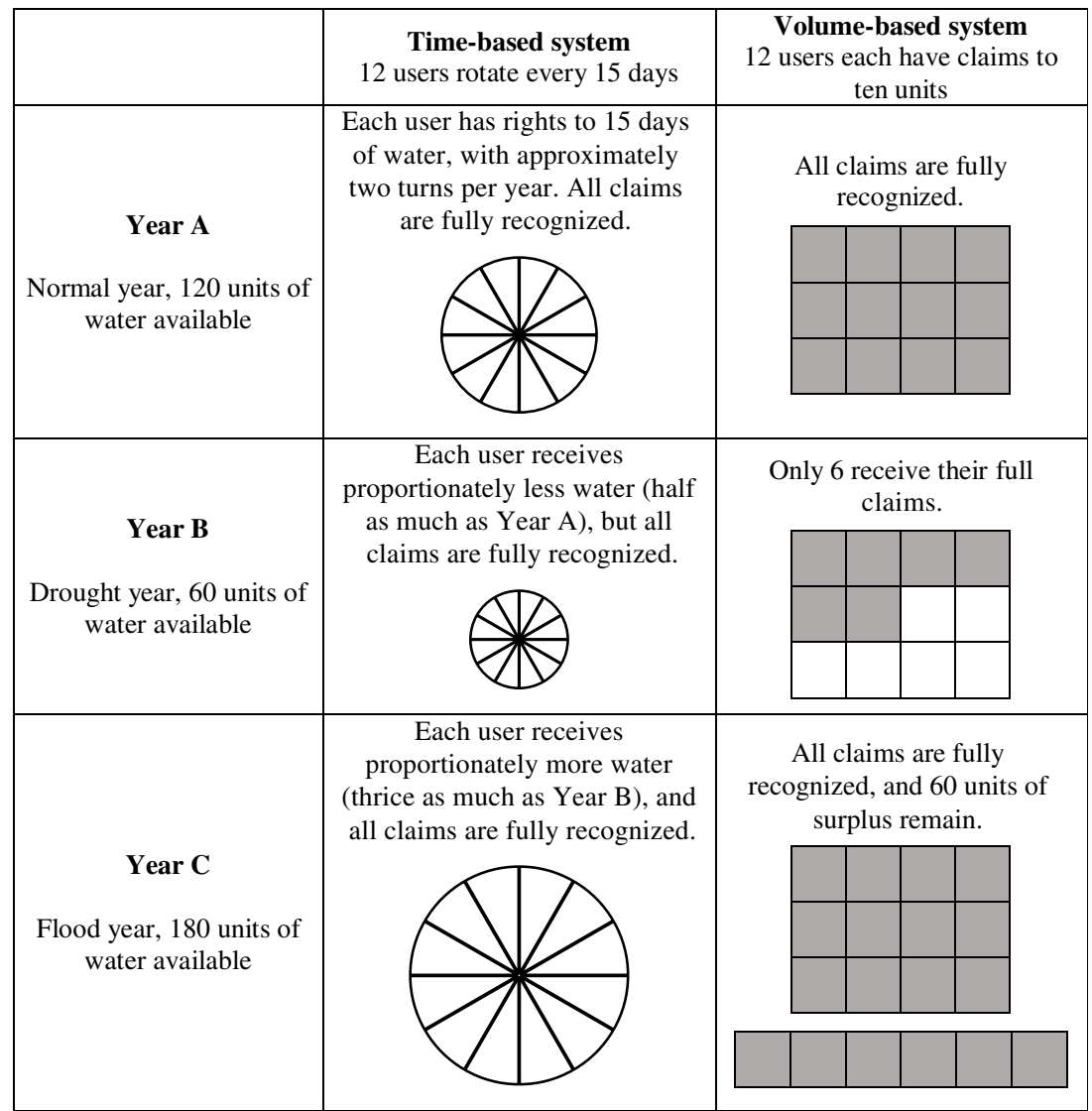

Figure 1.

A visualization of the differences between idealized versions of time and volumebased water rights. Credit: Courtesy of the author.

and a speculative land and water market. Standardized, volume-based measurements, as opposed to "one day" or "one week" of water, made water increasingly like an "arithmetical abstraction" and, in doing so, rendered it increasingly fungible and commodified. A standardized, volume-based unit is more easily convertible into other terms. It can be more easily equated to the exchange values of other commodities, making it more easily bought and sold.

The second, and perhaps more important, difference between time- and volumebased measures is that measuring water in time forces each user to understand his usage in terms of the larger community. If one user decides to take more than his share and increase his time at the spring, it cuts directly into someone else's time. Time-based sharing thus embeds water in a network of social relations. It reinforces the idea of water as a shared resource, emphasizes that it is finite, and ideally allows the community to share that finite amount. If a member of the community instead claims rights to a certain volume of water, he can effectively take from the spring until that amount is realized, regardless of what remains for others. There is no way of guaranteeing that the spring can support everyone's claim. Users no longer see their consumption in terms 
of one another but, rather, at the expense of one another. It is therefore a more exclusive system of property rights (see Figure 1).

The difference between a time- and volume-based system, therefore, is not just the adoption of a different unit or method of measuring but also the reconceptualization of the social relations that surround a water source. Measuring water in time allows users to take into account the natural properties of water - that it is neither constant nor infinite -and frames water as a collective resource of the community. When measuring water by time, each user receives his share, regardless of the volume or amount available. Measuring by volume, on the other hand, obscures water's natural properties and constraints, privileging the claims of the individual over the needs of the group. This is not to say that a time-based system is always fairer or more equitable in practice. Shares may still become the object of dispute (Nader 1985). Those with more resources can buy up or appropriate more shares, meaning that social hierarchies are reflected in inequitable proportions of water (Attia 1985; Hammoudi 1985). Certain turns might also be less desirable than others, such as those at night or during weekly days of rest (Hammoudi 1985).

What such possibilities illustrate is that a time-based distribution system is not simply a form of private property that creates a relationship between a person and a thing. It places the water user into a network of social relationships, and the nature of those relationships is both embedded in, and reflected by, the distribution of water (Hammoudi 1985; Nader 1985). Laura Nader (1985, 4) notes that, in the context of a time-based water-sharing system in the Drā Valley in Morocco, that "[p]atterns of individual rights and collective obligation must be identified in order to understand water distribution. Water received is one person's property, but at the same time it forms part of a network of collective rules and obligations." An incoming settler population is naturally going to disrupt such a network. Settlers have two options in such a situation. They can assimilate into a preexisting network by buying up time shares of a water source, requiring them to embed themselves in a web of social relationships. Or, conversely, they can find some other way of appropriating water. In the case of Mandate Palestine, this was by drilling and pumping groundwater and using volume-based measurements to delineate a new, exclusive set of water rights. ${ }^{16}$

\section{WATER INVESTMENT AND SPECULATION}

Differing ways of measuring water rights were but one piece of a larger picture. Because securing and developing water resources was seen as crucial to the Zionist project, there arose a high volume of traffic in water rights and a speculative water market. In this climate, time-based water rights became an obstacle to outside investment, frustrating both the British government and Jewish settlers. Because time-based water rights are embedded in a network of social relations, they obstruct potential outside

16. One could draw a loose analogy with the Drā Valley in Morocco, in which water sources were changed from the allam to the mulk system (from water being attached to land to water being detached) after conquest as a way of accommodating new users, especially nomads, who had no preexisting ties to the soil (Hammoudi, 39). Attia (1985) describes a similar situation surrounding the arrival of modern agriculture in Tunisia and the implementation of groundwater drilling and volume-based measurements. 
investment from someone not already in that community. If a group of farmers sharing a spring all define their usage based on time, there is no problem with collectively investing in an upgrade. They will each have the same time allotment before and after the upgrade, and everyone's output will increase equally. ${ }^{17}$ However, if an outside investor wants to upgrade the spring in order to increase the output and exploit the surplus, he cannot put money into the spring unless there is a guaranteed surplus of water that will come from that investment. Only a standardized, volume-based unit can denote a guaranteed amount of surplus water and, hence, guarantee a return. For example, in 1943, the British administration wanted to construct a masonry channel in Wadi Fari, ${ }^{18}$ but it could not do so because it would not be able to claim the new surplus supplied by the channel. Preexisting users who held rights to the water each held a period of time and would be able to claim any new surplus during their turn at the spring. ${ }^{19}$

In addition to often necessitating volume-based measurements, loans for water infrastructure sometimes decided de facto rights in place of disputed water ownership. It was not always clear if a loan applicant held rights to the sources that they wanted to develop. This was often the case when Jewish settlements applied for credit. The loan officer acted as a water arbiter because "[t]o approve loans in the absence of such settlement [of water rights] entails the tacit recognitions by Government of rights in water for the utilisation of which the loan is granted." ${ }^{20}$ Getting a loan, therefore, determined water rights simply by enabling one party to build the infrastructure to exploit the water in question. Settlements were able to take over water sources simply because they had access to credit.

Creating yet further confusion was the rise of a speculative market for water rights, which the director of development, Lewis French, attributed to the shift to intensive agriculture. ${ }^{21}$ In 1935, the British attorney general wrote in a memorandum:

Water rights are a frequent subject of commercial transactions; a man may sell half his land and the whole of his water rights or he may retain the whole of his land and sell half his water rights. It is, moreover, not uncommon for speculators, who own no land at all, to purchase the water rights in an area and to farm out the water thus required to the highest bidders. ${ }^{22}$

According to British officials, both speculation and partitioning communally held land disadvantaged users with fewer water rights ${ }^{23}$ and disorganized the time-based method of

17. Amos Nadan $(2003,337)$ describes a similar process for a group of farmers collectively developing communally owned land: "[T]he investment was shared, as well as the yield in due course."

18. Likely referring to Wadi al-Far'a, a village near Tubas.

19. Harold MacMichael to Oliver Stanley, August 9, 1944, CO 733/458/12, TNA. One iteration of the many proposed water ordinances had specific provisions to get around this problem. See Memorandum Explanatory," 11-12.

20. Minute, January 27, 1943, CO 733/440/20, TNA.

21. "French Report," 62-64.

22. "Memorandum on the Draft Palestine (Amendment) Order in Council No. 2 by the Attorney General," September 7, 1935, CO 733/303/6, TNA.

23. Memorandum Explanatory." 
water sharing. ${ }^{24}$ As speculation continued, a man who could not afford to develop his water was often forced to "sell his holding to a capitalist who can develop it." 25

Water was in such high demand that in 1920 the Jewish Agency even hired a sorcerer who was famed for finding underground petroleum, water, and mineral deposits to survey Palestine in search of groundwater. ${ }^{26}$ By the 1930 s, Zionist organizations began deep well boring - a process that requires expensive equipment, such as mechanical drills (Survey of Palestine 1946; Nadan 2006). Because underground water sources feed into springs and shallower wells, deep well boring often diminishes the supplies of neighboring water sources, leading effectively to appropriation. Infrastructure, such as a mechanical drill or pump, was therefore not only a way to secure water but also to take it from others. ${ }^{27}$ Those unable to invest in such infrastructure-typically, the fellaheen (peasant farmers) ${ }^{28}$ — were the most disadvantaged. Varying regimes of property rights were thus one complicating factor in a larger, chaotic environment.

\section{GRANTING THE CONCESSIONS}

In 1921, before the Palestine Mandate had been ratified, the high commissioner for Palestine granted Pinhas Rutenberg, a Russian Jewish immigrant, two concessions for the generation and supply of electricity in Palestine and Transjordan. The concessionaire was to generate hydropower from three rivers- the 'Auja, Jordan, and Yarmuk-as well as supply irrigation from the 'Auja. Significantly, the concessions gave Rutenberg rights of expropriation and forbade preexisting users of these rivers from increasing their water usage. Rutenberg was thus given the unique authority early on in the Mandate to expropriate, destroy, and lay significant infrastructure over a large territorial area. The PEC eventually took over both of these grants, vesting these powers in the corporation itself (Shamir 2013).

These concessions were important from the outset, not only because the electric supply they were to generate had the potential to transform the region's economy, but also because they granted broad control over three of Palestine's major rivers. It is for this reason that the issue of water use during the Mandate cannot be understood separately from that of electricity. As such, the concessions generated a significant amount of controversy. While the significance of granting control over these rivers was not fully grasped from the outset, the ramifications would become clearer over time. They were understood from the start, however, by at least some Palestinians as blatant Zionist favoritism that excluded them from the economic life of the country.

24. Irrigation Service Interim Report no. 1 by Dawson Shepherd," 1929, CO 733/174/9, TNA.

25. "Report of Irrigation Committee," November 13, 1929, CO 733/203/1, TNA.

26. "Summary of a Letter from Abr. Max Bourcart to the Zionist Organization," January 22, 1920, Z4/ 40002-26, CZA.

27. See, for example, Schorr 2014. There are also numerous contemporary accounts of the lowering of the water table in various areas. Survey of Palestine 1946; Letter from Dawson Shepherd, Aug. 22, 1933, CO $733 / 248 / 3$, TNA.

28. For an exploration of the class structure of the fellaheen, as well as the social and economic upheaval they experienced during the Mandate, see Abdo-Zubi 1989. 
During a 1922 debate in the House of Commons, some opposed the concessions, while others championed them as economic progress, a source of job creation, and an affirmation of the Balfour Declaration. Winston Churchill, then secretary of state for the colonies, described the concessions as creating a "new Palestinian world ... a good gift which the Zionists could bring with them. Left to themselves, the Arabs of Palestine would not have in a thousand years have taken effective steps towards the irrigation and electrification of Palestine." 29 The "gift" of electricity and irrigation, therefore, was part of colonial tutelage and the task of civilizing a backward population. Yet the concessions also solved a more pragmatic issue-funding. Churchill emphasized that the concessions would alleviate the British government's burden of financing public works in Palestine. Any British development project would have to be funded by a loan, but electrification did not promise profit or the ability to repay such a loan (Shamir 2013). ${ }^{30}$ Churchill argued that Rutenberg could raise the capital, and Baron Edmond de Rothschild would fund him on non-commercial terms. ${ }^{31}$

Arabs protested the concessions through official and informal channels. Despite contemporary stereotypes of Palestine as a feudal, uncultivated desert, Sherene Seikaly (2016) has shown that the area was, during the Mandate period, experiencing an economic nahda (renaissance) of cultural and economic thought. This is reflected in some of the arguments against the concessions. The Palestine Arab delegation communicated in writing to the Colonial Office in 1922 their upset at the granting of monopolistic rights to public works: "The Zionists, through Mr. Rutenberg, are aiming at getting a stranglehold on the economics of Palestine, and once these are in their hands they become virtual masters of the country. ${ }^{32}$ The delegation further argued that the concessions should have at least been put to public tender, allowing for basic competition. What else are economic and social matters like financing public works, they queried, if not "the entire life of the country?"33

Arabs in Palestine and Transjordan also protested in more informal ways, such as through boycotts. ${ }^{34}$ Many refused to hook up to the grid, and Transjordan went for years without electricity or industrial development as a result (Konikoff 1946). In 1923, in Palestine, residents of Jaffa and the surrounding orange groves similarly boycotted the power (Shamir 2013). In fact, in the early 1920s, hardly any demand for electricity existed beyond Tel Aviv, and the idea of building another powerhouse on the

29. House of Commons Debates, July 4, 1922, series 5, vol. 156, column 293-341.

30. Ronen Shamir (2017) also stresses that there were no banking institutions in Britain at the time that could finance such a loan.

31. Yet even this could not have been Churchill's only consideration. Prior to Rutenberg, both British and Palestinians had submitted applications for electricity concessions to the British administration. Even though the latter party was willing to use their own capital for financing, their applications were all denied. In addition to the July 4, 1922 debate, see "Palestine. The Rutenberg Concession," July 5, 1922, CAOG 14/ 109, TNA; "The Palestine Arab Case, Injustice of Present Policy," enclosure to a letter from the Palestine Arab Delegation to Prime Minister Bonar Law, January 11, 1923, PREM 1/24, TNA.

32. Correspondence 1922, 23.

33. Correspondence 1922, 23.

34. This is not to imply that Palestinians were completely united in opposition. As Shamir (2013) has shown, some were not opposed to the promise of an electric supply. 
Jordan, which the concessions had authorized, appeared absurd. ${ }^{35}$ While Jaffa ultimately connected, many continued to oppose the scheme. ${ }^{36}$

Given the protests from the Palestine Arab delegation, granting the concessions cannot be fully understood simply as a benign peace offering or "good gift" to the Palestinians. In more honest terms, the chief secretary to the high commissioner for Palestine wrote in 1921 that the "Rutenberg Concession is as much a part of the Mandate as if it had actually been included in it. There has never been any doubt in my mind that the Rutenberg Concession must go through, and that it must go through whether the people of Palestine agree with it or not." 37 British officials knew that they were going against the wishes of at least some part of the population. The concessions, therefore, were not merely a well-intentioned scheme of good governance or pacification.

\section{CORPORATE VOTING RIGHTS}

On its surface, the Rutenberg concessions may seem like a rather benign form of favoritism. After all, the PEC did employ and provide electricity to Jewish settlers and Palestinians alike. The catch, however, was that Rutenberg and other initial investors designed the PEC's corporate structure to keep management of the company in Zionist hands. The corporate form thus functioned as a vehicle of exclusion, delineating who could and could not exercise control over electric production and, by extension, rivers, in Palestine. This can be understood, at least in part, in the context of Rutenberg's own personal Zionist orientation, which differed from Labor Zionism, the branch that would become the most mainstream.

Labor Zionism favored exclusively "Hebrew labor," meaning a segregated, wholly Jewish workforce, as a colonizing strategy. Because homogenous Jewish labor was difficult to achieve over a wide geographic base, Labor Zionism was willing to forgo geographic expansion over the entirety of historic Eretz Israel in order to not sacrifice Jewish autonomy. It was also expensive. Jewish labor was, on the whole, more costly than Palestinian labor. Central labor institutions, such as the kibbutz, succeeded in large part because they were funded on non-commercial terms and thus shielded from capitalist market imperatives (Shafir 1989; Wolfe 2012). Rutenberg, however, did not

35. See, for example, M. Elsasser to Bernard Flexner, November 26, 1923, A405/147/1, CZA. The concessions were also challenged in the international community. Between 1922 and 1926, Greece sued Great Britain thrice in the Permanent Court of International Justice (PCIJ) because the Rutenberg concessions violated previous grants for the generation of electricity made by the Ottoman government to a Greek individual. The only portion of those concessions that survived the PCIJ lawsuits was the right to provide electricity in Jerusalem, which was taken over by the Jerusalem Electric and Public Service Corporation. This was the only exception to the PEC's otherwise geographic monopoly over electric generation and supply. Because of the lawsuits, the Jordan concession was not finalized until 1926, and the Jordan powerhouse did not open until the early 1930s (Shamir 2013). This delay in the building of the Jordan powerhouse provided time for the consumer base and demand for electricity to grow.

36. For instances of boycott and protest later in the Mandate, see "Minute by A. C. C. Parkinson," October 20, 1938, CO 733/374/12, TNA; "Blow to Rutenberg Monopoly, Jaffa Refuses to Pay," May 11, 1925, CAOG 14/108, TNA.

37. Wyndam H. Deeds to Sir John Shuckburgh, December 22, 1921, CO 537/854, TNA. 
espouse such views. He was part of the Revisionist strand, which would accept integrated Jewish-Arab labor but was more adamant in its demand for geographic expansion and territorial integrity. He was also an ardent capitalist, and his penchant for profit making often put him at odds with the Zionist establishment. ${ }^{38}$

Rutenberg and his initial investors structured the PEC so that anyone-Jew or Arab-could be a shareholder, but with the caveat that shares with full voting rights would remain firmly in Zionist hands. Rutenberg knew that the corporation would have to issue shares in order to raise enough capital to build the hydroelectric plants and that he would have to "allow" Arabs to purchase these shares, "but he did not want them to have any voice in the concession themselves." ${ }^{39}$ Management was to remain in Zionist control. He and his initial investors achieved this by constructing three classes of shareholders, each with a different set of voting rights. Ordinary shareholders had full voting rights, preference shareholders had conditional voting rights, and ordinary "A" shareholders held no voting rights. The only ordinary shareholders, and, therefore, the only ones with full voting privileges, were five Zionist groups: the Palestine Jewish Colonization Organization, the Jewish Colonial Trust, the Palestine Development Council, the Joint Distribution Committee, and the Economic Board. The preference and ordinary "A" shares were offered for general subscription, meaning that anyone could buy them, but they could not vote on management issues. ${ }^{40}$

Rutenberg's concern, therefore, was not about Arabs subscribing to shares, gaining employment, or connecting to the electric grid but, rather, about them having a voice in electricity and irrigation in Palestine. ${ }^{41}$ In Rutenberg's own words, in a 1923 letter to US Judge Julian Mack, "I succeeded in creating a powerful political and economic instrument for the Jewish people in Palestine. And this instrument I have placed at the disposal of my people." 42 Another frantic letter, written over a decade later in 1934, worried about where certain shares were going: "Mr. Rutenberg has been complaining that we are selling shares to Arabs, and thus endangering the fate of the most important institution of which, since our Father Abraham's time the Jewish people can boast." 43

The PEC itself, therefore, was far from neutral. Its structure embedded a hierarchy of those who owned, managed, and controlled the concessions, those whom the concessions

38. Shamir $(2013,158 n 8)$ argues that, given Pinhas Rutenberg's distance from the "Zionist establishment," "it would be wrong to account for his activities in matters related to the electrification of Palestine in terms of Zionist 'interests'." While it is true that Rutenberg did not affiliate with either Labor Zionism or the Zionist Organization and that the latter often went against the interests of the PEC and vice versa, we still have to understand the PEC in terms of Zionist interests more broadly. At base, Rutenberg believed in the creation of a Jewish nation in Palestine, and, while his methods differed significantly from other Zionist leaders, he understood his work as benefiting the larger Zionist project.

39. "Detailed Report to Judge Mack by Samuel J. Rosensohn," July 19, 1922, A405/42/B, CZA.

40. Preference shareholders could only vote if the rights or privileges of their shares were under discussion or if dividends were in arrears. "Palestine Electric Corporation Limited Report," undated, S90/2230/ 37, CZA; J. E. Palmer Tomkinson to Mr. Baker, n.d., L51/404, CZA; "Detailed Report to Judge Mack by Samuel J. Rosensohn,” July 19, 1922, A101/121, CZA.

41. In fact, Shamir $(2013,65)$ shows that Rutenberg gave orders "to speak Arabic and treat Arab consumers and population in general in the most correct and friendly manner" and for "Arab labor to be employed as much as possible."

42. Letter from Pinhas Rutenberg to US Judge Julian Mack, January 30, 1923, A101/121, CZA.

43. Letter to D. Israeli (unsigned), October 23, 1934, L51/405, CZA. 
employed or connected to the grid, and, finally, those who boycotted or could not afford to access the grid altogether. In 1940, one British official wrote that Rutenberg's plan was to secure "Jewish economic predominance in Palestine as a step towards political supremacy." 44 In addition to facilitating Zionist control, the PEC also directed foreign investment into Palestine. In 1935, the corporation made a public offering in London of ordinary "A" and preference shares, drawing mostly non-Jewish investors. The idea of the "development of Palestine or "the Holy Land"' appealed to the British public. A London-based AngloPalestine Bank employee wrote: "[T]here is an association of ideas, people being attracted by the word 'Palestine' both in the name of the [Palestine Electric] Company and in our own name, and use is being made of us accordingly." 45 The 1935 public offering was oversubscribed, ${ }^{46}$ and, as a result, many shareholders lived in Britain.

None of this would have been possible, however, without volume-based measures. The PEC appealed to foreign investors through brochures and prospectuses that surveyed Palestine's water resources in cubic meters and used those measurements to calculate potential kilowatt hours. ${ }^{47}$ Measuring water in this way allowed Rutenberg to make Palestine's water legible to foreign investors. A prospective shareholder in London would not have understood days of water, but cubic meters and kilowatt hours were recognizable from afar.

The ability of the corporate form to funnel foreign capital into Palestine is significant for two reasons. First, by 1934, the British government could no longer afford to buy out the PEC. ${ }^{48}$ As a result, the PEC was able to go against the administration when their interests conflicted and assert a kind of de facto sovereignty, to be discussed more below. Second, the success of this corporate model complicates conventional narratives that frame Zionist colonization as a socialist endeavor. Numerous scholars have highlighted the fact that, unlike in other settler colonies, money invested in Zionist settlement did not expect a return on investment (Smith 1993; Wolfe 2012). Yet the project of electrification itself, like Rutenberg's outlook, was fundamentally capitalist in nature, and it was crucial to the development of a Zionist economy (Shamir 2013). While Rutenberg could outwardly claim that electrification served both parties equally, in reality, it benefited Zionists and systematically excluded Palestinians from any kind of meaningful ownership of the means of electric production.

\section{THE PEC'S WATER MONOPOLY}

With control over the 'Auja, Jordan, and Yarmuk rivers, the PEC exercised an effective monopoly over surface water in northern Palestine-a monopoly that was felt in various ways by Jewish settlers, Palestinians, and the British administration alike. One such way was the PEC's hydroelectric works on the Jordan River, which severely

44. "Minute by Downie," June 3, 1940, CO 733/426/10, TNA.

45. Anglo-Palestine Bank to D. Israeli, March 15, 1935, L51/405, CZA.

46. Barclays estimated twenty million pounds sterling worth of applications within a week of the public offering. Letter from H. R. Baker to S. Hoofien, February 21, 1935, L51/405, CZA.

47. I owe the insight that volume-based measurements are required to calculate kilowatt hours to Owain Lawson and Ronen Shamir. For an example of one such prospectus, see Hydro-Electric Development 1922.

48. "Minute from H. Downie to Williams," May 16, 1934, CO 733/268/1, TNA. 
constricted both up and downstream users. Generating hydroelectricity requires specific physical conditions. Upstream water must flow at a rate and volume significant enough to produce power. For this reason, the PEC effectively controlled Lake Tiberias, just upstream of the powerhouse, using it as a holding basin for water and managing lake levels according to generator needs. ${ }^{49}$

The PEC also exercised upstream control even further north, over Lake Huleh. The Jewish Agency wanted to drain Lake Huleh and reclaim the land-a project that would eventually be completed later-but losing the lake as a reservoir would have cost the PEC fifty thousand horsepower of electric capacity. ${ }^{50}$ Rutenberg and the Jewish Agency agreed to not drain the lake and instead compromised on using a portion of the water for irrigation. ${ }^{51}$

Downstream users, on the other hand, were disadvantaged by the low angle at which the water exited the Jordan powerhouse. Since, in the process of electric production, the water's kinetic energy has already been harnessed for electricity (Gupta 2006), the water requires added energy, such as pumping, to raise it again and make it productive. One frustrated official wrote to the secretary of state for the colonies in 1937 that "water cannot be tapped until it has passed through the turbines, by which time it is at too low a level to be of practical value." 52 Pumping on any large scale to make use of the water downstream would have been expensive and energy intensive, requiring either the purchase of electricity from the corporation or access to some other energy source. In 1937, one British official labelled the PEC "a hostile vested interest," ${ }^{23}$ preventing agricultural development of the Jordan Valley, a charge that Rutenberg denied. ${ }^{54}$ In 1943, the PEC even refused to let the administration use the Jordan and Yarmuk for wartime irrigation (Survey of Palestine 1946).

The PEC also refused to exercise its rights to irrigation, making the 'Auja inaccessible to local farmers, many of whom were Jewish. Without access to this river, many turned to energy-intensive groundwater pumping for irrigation, which created a large local demand for electricity. Because an 'Auja irrigation scheme would have generated more than enough water to meet agricultural needs, thereby obviating this demand for electricity, the PEC had no incentive to create an irrigation scheme (Shamir 2013). From the British perspective, building such a scheme had been a key aim of the concession. By refusing to follow through, the corporation was "prevent[ing] adequate utilisation of one of the most important sources of irrigation in Palestine." 55 The

49. This decreased fish life in the lake ("Annual Report of the Department of Agriculture and Forests," 1933-34, CO 733/273/6, BNA), exposed submerged land, created a malaria hazard, and changed the lake's aesthetics (letter from W. M. Christie to the Secretary of State of the Colonies, June 2, 1938, CO 733/374/ 12, TNA; "Note on the Effect of Altering the Level of Lake Tiberias on the Appearance of the Lake," October 5, 1934, CO 733/268/2, TNA).

50. Letter to Sir John Shuckburgh, April 21, 1925, S25/7416-59, CZA.

51. "Note of Conversation with Mr. P. Rutenberg," June 14, 1934, CO 733/268/1, TNA; Sir John Shuckburgh to Secretary of State for the Colonies, September 29, 1926, Z4/42461-92, CZA.

52. Letter to Ormsby-Gore, Secretary of State for the Colonies, September 14, 1937, CO 733/337/2, TNA (emphasis in the original).

53. "Minute by Bennet," October 4, 1937, CO 733/337/2, TNA. TNA.

54. Pinhas Rutenberg to the Under Secretary of State for the Colonies, July 29, 1937, CO 733/337/2,

55. Letter from J. H. Thomas, October 15, 1931, CO 733/203/1, TNA. 
administration and the PEC struggled for six years on this issue, and, as a result, the 'Auja remained largely inaccessible to irrigators over the course of the Mandate.

In addition to refusing to build any irrigation schemes, the PEC also actively prevented cultivators from drawing water from the Jordan, Yarmuk, and 'Auja rivers (Gaarde 2006). For example, in 1932, the PEC sued an Arab farmer for using the 'Auja. ${ }^{56}$ By 1935, at least four appellate cases claimed preexisting rights to the river for irrigation. ${ }^{57}$ In another incident, the PEC wanted the government to expropriate Jordan and Yarmuk water from the fellaheen in the Huleh basin. The high commissioner refused, arguing that to do so would trigger the "depopulation" of the basin and areas of the Transjordan. He did, however, make loans to these populations contingent upon the corporation's approval of their water usage. ${ }^{58}$

By making these rivers inaccessible, the PEC successfully created a demand for its product among those who, left without any alternative water source, could afford to pump groundwater. By the 1930s, pumping groundwater in fact became the PEC's largest demand for electricity, followed by industry. Domestic use and streetlamps trailed behind in a distant third and fourth place (Faris 1936). ${ }^{59}$ The eventual result was over-pumping. By 1930, citrus cultivating areas were already experiencing salinity and a decrease in the water table. By 1946, such effects had spread to Haifa, Tel Aviv, and the Lydda-Rehovoth-Rishon area, south of the 'Auja (Survey of Palestine 1946).

This effective river monopoly continued until even after the formation of the State of Israel. When the United Nations Relief and Works Agency (UNRWA) wanted to develop the Yarmuk and Jordan rivers as part of a settlement program for Palestinian refugees, the PEC challenged UNRWA's rights to the water and put forth its own scheme for the settlement project. In effect, the PEC was willing to sabotage UNRWA's program in order to take advantage of settling Palestinians as a profitable scheme, despite the fact that UNRWA was the "only hope of Jordon [sic] of settling a large number of refugees." 60 Finally, in 1953, the State of Israel purchased half of the PEC's share capital ${ }^{61}$ and changed its name to the Israel Electric Corporation, which is how it is still known today (Shamir 2013).

With the help of the corporate form, Rutenberg took rivers that had long been locally used and put them under foreign control. The PEC was arranged in such a way as to not only systematically exclude Palestinians from that control but also to amass enough power to be able to assert a kind of de facto sovereignty vis-à-vis the

56. "Fate of Concessions," Falastin Clipping, March 19, 1932, CAOG 14/108, TNA.

57. "Water Rights in the "Auja Basin," Palestine Post, March 1, 1935, S90/2230/37, CZA; "Memorandum on Order in Council No. 2."

58. "Minute," by V. Glenday, January 1, 1943, CO 733/440/20, TNA; High Commissioner Harold MacMichael to Oliver F. G. Stanley Secretary of State, December 10, 1942, CO 733/440/20, TNA.

59. In Syria, domestic use was the highest demand for electricity at this time, indicating that the high demand for irrigation may have been atypical and specific to Palestinian conditions (Faris 1936). It is also noteworthy that connecting to the electric grid was expensive and generally required access to credit. Many municipalities, often Arab, could not afford to do so (Shamir 2013). Rutenberg facilitated loans to Jewish settlements to enable them to connect to the grid but did not do the same for Palestinian settlements. Letter from Pinhas Rutenberg to S. Hoofien, October 19, 1926, L51/347, CZA.

60. Record of a Meeting Held at the Foreign Office," May 7, 1953, FO 371/104952, TNA.

61. Palestine Electric Corporation newspaper clipping, August 28, 1953, FO 371/104953, TNA. 
British administration. This de facto sovereignty ultimately enabled the corporation to exercise a river monopoly, policing farmers who attempted to use more water than the PEC deemed acceptable and blocking any large-scale irrigation scheme.

\section{FAILURE TO REGULATE}

Whether to regulate irrigation was another key debate on which the British administration, Rutenburg and the PEC, and the Jewish Agency all took different positions. Legal regulation of surface and groundwater was a prerequisite for both government-led water development and for solving the problems of water rights, speculation, and irrigation, which have been detailed above. ${ }^{62}$ According to the director of development, Lewis French, intensive agriculture was "squeeze[ing] out" poorer farmers, "and the ownership of water in the free-flow areas [was] tending to pass into the hands of the capitalist who usually by the common Oriental methods gets more than his fair share of water." ${ }^{3}$

The conflict over regulation further demonstrates the space between the Jewish Agency and the PEC. The corporation wanted the administration to regulate well drilling and take ownership of, and levy a rate on, all underground water. Rutenberg maintained that this was a prerequisite for building the 'Auja irrigation scheme discussed above. As long as farmers were able to pump free water from their own wells, there would be no financial incentive to use another source of irrigation, and an 'Auja irrigation scheme would be "commercially untenable." ${ }^{4}$ The PEC essentially wanted to cut users off from free water, making them reliant on either the corporation's electricity for pumping or on a future irrigation scheme. Rutenberg's priority was, in essence, profit making.

Conversely, the Jewish Agency objected to regulation because they had "benefited much under the present chaotic conditions." ${ }^{65}$ As discussed above, Jewish settlers were able to secure water rights in a speculative market. The British government wanted to rejoin water to its appurtenant land in perpetuity, ${ }^{66}$ which would have impeded the buying up of water rights and possibly invalidated water rights already purchased and acquired (Shamir 2013). Furthermore, because the Jewish Agency had invested in deep well boring, they wanted to keep underground sources unregulated (Gaarde 2006). ${ }^{67}$ The Jewish Agency thus took a different approach from the PEC. The corporation favored limiting public access to water in order to generate revenue from it,

62. D. G. Harris, Irrigation Advisor, "Note on the Proposed Irrigation Ordinance," February 8, 1935, CO 733/284/3, TNA.

63. The phrase "by the common Oriental methods" was later omitted. "French Report," 64.

64. "Opinion by the Acting Attorney-General with Regard to Irrigation Rights under the "Auja Concession, enclosure to a dispatch to Lord Passfield, Secretary of State for the Colonies, May 6, 1931, CO 733/203/1, TNA.

65. "Minute," by V. Glenday, January 1, 1943, CO 733/440/20, TNA.

66. "Draft," Palestine Gazette, no. 1185, April 9, 1942, KKL8/133, CZA; Memorandum Explanatory." The British government based its draft ordinance on Elwood Mead's treatise, "Irrigated Institutions," which was formulated in response to the economic and legal questions created by the growth of irrigated agriculture in the Western United States, another settler colonial context. Harris, "Note on the Proposed Irrigation Ordinance."

67. For a good example of the lobbying language used by the Jewish Agency, see Bernard Joseph to Chief Secretary, Government Offices, Jerusalem, March 8, 1942, KKL8/130, CZA. 
while the Jewish Agency expended money to amass water rights and underground sources. The PEC's method was profitable, while the Jewish Agency's was expensive. The British colonial government, on the other hand, agreed with neither party. The administration wanted control over surplus water only. Taking ownership of all water, as Rutenberg advocated, would have been too far of a step away from the former Ottoman law ${ }^{68}$ and costly, as the administration would have had to reimburse owners for expropriated water. ${ }^{69}$

Finally, in 1943, the colonial government ended fifteen years of attempts to pass irrigation ordinances. While no Arab representatives objected to legislation, ${ }^{70}$ the administration wanted to avoid a "first-class issue" with the Jewish Agency, which had "the most violent feelings" on the subject. ${ }^{71}$ Despite the government's desire to regulate and develop irrigation, water rights remained ambiguous, speculation persisted, and the rivers were cut off from use. This ultimately most disadvantaged those without access to capital or credit, such as the fellaheen.

\section{SABOTAGE AT A DISTANCE}

One of the most salient effects of the PEC is that it essentially cut off Palestine's rivers from common use, taking water that had previously been under local control and placing it under the management of foreign shareholders. The PEC thus amassed and exercised a significant amount of power-power that can be best understood not only in terms of its control over water but also in its ability to deny that water to others, to withhold it from the community. The result was, in the words of French, "an apparent stranglehold on all irrigational enterprise other than the concessionaire's operations." ${ }^{.2}$

Writing in the early twentieth century, Thorstein Veblen (1923) describes this ability to withhold as the "legal right of sabotage," part of what he calls "absentee ownership" of natural resources. Absentee ownership differs from Lockean formulations of property that see ownership as deriving from mixing one's labor with what one owns. Rather, in absentee ownership, what one owns is loaned to others to work. Ownership and workmanship are split. The legal right of sabotage is the ability to not loan what one owns out to work, withholding it from workers and from the market. Because absentee ownership is not derived from labor, it typically originates in an act of expropriation or seizure, "legalized by statute or confirmed by long undisturbed possession" (51).

One could loosely describe the PEC's control over Palestine's rivers as power, but Veblen's (1923) concept of sabotage helps get at a more precise understanding of what that power was and how it functioned. It operated by cutting off supply, by limiting the ways in which people could use their water, and by making them dependent upon the electric grid. By withholding rivers from common use and refusing to build any irrigation projects, Palestine's rivers were denied from the community at large. Moreover, the PEC's effective ownership of Palestine's rivers stemmed precisely from this kind of

68. Letter from J. H. Thomas, October 15, 1931, CO 733/203/1, TNA.

69. "Minute by H. E. Priestman," June 13, 1931, CO 733/203/1, TNA.

70. "Minute," by V. Glenday, January 1, 1943, CO 733/440/20, TNA.

71. "Minute," to Secretary of State, April 16, 1943, CO 733/400/21, TNA.

72. Lewis French to the High Commissioner, November 23, 1931, CO 733/224/12, TNA. 
seizure, which was deemed legitimate by the granting of concessions by the British administration when it had only just become the governing Mandatory authority.

The theme of "present absenteeism" appears often in Palestinian studies. To begin with, it is often argued that many Jewish European settlers purchased land before and during the Mandate from absentee landowners-landlords in Syria or Lebanon with little understanding of what was going on in Palestine (Wolfe 2012). ${ }^{73}$ Second, after the creation of the State of Israel, the new government created a special category for displaced Palestinians who remained inside the Jewish state, "present absentee," essentially internal refugees who, in many cases, were never able to return to their homes (Masalha 2005). The category thus holds a specific place in Palestinian memory. In this instance, however, it was the PEC's foreign shareholders, and not Palestinians, who were the present absentees. This kind of absentee ownership - a corporation with many shareholders in Britain and the United States that controlled the water used by farmers in Palestine-constitutes what Veblen $(1923,66)$ calls "sabotage at a distance" and likely shares many similarities with the multinational corporation today. Sabotage at a distance directed foreign capital into Palestine, kept Palestine's rivers idle, and, in doing so, shifted social and economic relations.

The power to withhold water and electricity was enhanced as more people depended on the corporation. Rutenberg and the PEC's directors therefore wanted as many people as possible — whether Jewish or Arab— to depend on its electric grid. ${ }^{74}$ The number of connected electric appliances increased five-fold in two years, from 1,649 in 1932 to 8,300 in 1934, and the number of motors rose from 2,082 in 1931 to 6,379 in 1934 (Faris 1936). Yet, by making people, agriculture, and industry reliant on electricity, the PEC also created a point of vulnerability-the grid itself. During the 1936-39 Arab Revolt, the PEC's fixtures and irrigation systems became points of counter-sabotage. In 1938, transmission lines were attacked. The corporation sent repair workers to the site, who were attacked and killed. The notifying telegram intimated the danger of losing electric supply: "Failure safeguard supply bound result ruin orange crop dislocating industry and security towns." 75 While not sabotage in Veblen's sense of the term, damaging and disrupting colonial infrastructure was a method of disrupting the new status quo.

Palestinians continued using alternatives to electricity throughout the Mandate, likely largely because of the prohibitive cost of connecting to the grid. By 1932, kerosene remained the dominant energy source in Palestine, providing a cheaper alternative for heating, cooking, and lighting. By 1936, however, kerosene usage declined in Haifa, Tiberias, and Jaffa, where the PEC operated, and increased in Nablus, where there was no electric supply (Faris 1936). A 1936 report noted a "shift, by a large number of

73. In Patrick Wolfe's $(2012,155)$ words, “[m]uch has been made of these absentee landowners, whom Zionists liked to characterise as unscrupulous orientals bearing responsibility for their humbler countrymen's misfortunes." For a good unpacking of this stereotype and exploration of the reasons for these land sales, see Abdo-Zubi 1989.

74. According to Rutenberg, it enhanced "the security of their instillations all over the country that the maximum number of people should be interested in maintenance of [electric] supply." "Gist of interview with Mr. P. Rutenberg, Managing Director of the Palestine Electric Corp.," June 3, 1934, CO 733/268/1, TNA.

75. Translation of coded cable received from HAIFA, September 12, 1938, CO 733/374/12, TNA. 
[citrus] growers, back to Diesel motors and gasoline engines," although the cause is unknown (Faris 1936, 167).

\section{CONCLUSION}

The appropriation of Palestinian water thus occurred in many different ways during the Mandate. Some types of appropriation were intimate and local. For farmers who measured their share of water in hours or days, water use was embedded in complex networks of community relationships and composed the temporal rhythm of daily life (Peteet 2018; Seikaly 2019). With Zionist settlement, however, time-based water sharing increasingly came into tension with a different kind of property regime, one that understood rights to water as claims to a definite amount. Measuring water by volume abstracted away water use from the social context in which it had previously been immersed, making it more easily bought and sold. Given the larger speculative market and high demand for water, many farmers sold off their water shifts.

Other methods of appropriation functioned on a larger scale. Using volume-based measures to calculate electrical energy, Rutenberg transformed Palestine's rivers into an object of investment, placing them under foreign control. The PEC excluded Palestinians both from meaningful ownership of these means of production and from using rivers that had previously been open to common use. By amassing such economic power, the PEC was ultimately able to assert a kind of sovereign authority when it came into conflict with the British administration. What this shows is a discrepancy between the way in which settler colonialism understands and justifies itself and the way it operates in actuality. In the case of Palestine, exploiting water was framed as part of the efficient utilization of natural resources. The drive for transitioning from extensive to intensive agriculture, of which irrigation was such a central part, was undoubtedly partly based in a Lockean understanding of property (Shafir 1989; Wolfe 2012) and in the concept of colonial tutelage that lay at the heart of the Mandate system (Anghie 2005). Both British officials and Zionist settlers believed they knew how to use water better than the native population.

In actuality, however, settler colonialism sustained itself through legalized processes of exclusion. Appropriation of water, both in the case of new, volume-based measures and of the PEC, came not through better workmanship or more sophisticated forms of water use but, rather, through transforming water into an investment-an object that could be held exclusively, easily bought and sold, and, in the case of the PEC, on which money could be made. The introduction of new measures, the exploitative use of the corporate form, and the monopoly established over Palestine's rivers, as well as the larger Mandate itself, were each legal frameworks that in some way subordinated Palestinians. Given this narrative, it might be tempting to see one of these property regimes as becoming ever more present and one of them as becoming ever more absent over the course of the Mandate-volume-based, exclusive rights gradually eclipsing time-based practices. Yet this may not be entirely true. During the Mandate, Palestinians were able to block outside investment by using time-based sharing. Some even actively resisted the PEC's grid. To this day, Battir still has an eight-day week. The process, as we can see, is more complicated and still ongoing. 


\section{REFERENCES}

Abdo-Zubi, Nahla. 1989. "Colonial Capitalism and Rural Class Formation: An Analysis of the Processes of Social, Economic and Political Change in Palestine, 1920-1947." PhD diss., University of Toronto.

Anghie, Antony. 2005. Imperialism, Sovereignty and the Making of International Law. Cambridge, UK: Cambridge University Press.

Attia, Habib. 1985. "Water-Sharing Rights in the Jerid Oasis of Tunisia." In Property, Social Structure, and Law in the Modern Middle East, edited by Ann Elizabeth Mayer, 85-106. Albany, NY: State University of New York.

"Balfour Declaration 1917," Yale Law School: The Avalon Project: Documents in Law, History and Diplomacy. Accessed October 25, 2021, https://avalon.law.yale.edu/20th_century/balfour.asp.

Correspondence with the Palestine Arab Delegation and the Zionist Organisation. 1922. London: His Majesty's Stationary Office.

Cronon, William. 1991. Nature's Metropolis: Chicago and the Great West. New York: W. W. Norton \& Company.

Faris, A. Basim. 1936. Electric Power in Syria and Palestine. Beirut: American University of Beirut Press.

Gaarde, K. 2006. "British Colonial Water Legislation in Mandatory Palestine." In A History of Water: The Political Economy of Water, edited by Richard Coopey and Terje Tvedt, 172-90. New York: I. B. Tauris \& Company.

Glick, Thomas. 1970. Irrigation and Society in Medieval Valencia. Cambridge, UK: Belknap Press of Harvard University Press.

Gupta, S. C. 2006. Fluid Mechanics and Hydraulic Machines. Delhi: Dorling Kindersley.

Hammoudi, Abdellah. 1985. "Substance and Relation: Water Rights and Water Distribution in the Drā Valley." In Property, Social Structure, and Law in the Modern Middle East, edited by Ann Elizabeth Mayer, 27-57. Albany, NY: State University of New York.

Hydro-Electric Development of Palestine: The Rutenberg Project, Detailed Prospectus. 1922. New York: Palestine Development Council.

Kershner, Isabel. 2012. "A Palestinian Village Tries to Protect a Terraced Ancient Wonder of Agriculture.” New York Times, June 25. http://www.nytimes.com/2012/06/26/world/middleeast/ palestinian-village-tries-to-protect-landmark.html?_r $=0$.

Konikoff, Adolf. 1946. Transjordan, An Economic Survey. Jerusalem: Economic Research Institute of the Jewish Agency for Palestine.

Kula, Witold. 1986. Measures and Men. Translated by R. Szreter. Princeton, NJ: Princeton University Press.

Masalha, Nur. 2005. "Introduction." In Catastrophe Remembered: Palestine, Israel and the Internal Refugees: Essays in Memory of Edward Said (1935-2003), edited by Nur Masalha, 1-20. London: Zed Books.

Mitchell, Timothy. 2002. Rule of Experts: Egypt, Techno-politics, Modernity. Berkeley: University of California Press.

Nadan, Amos. 2003. "Colonial Misunderstanding of an Efficient Peasant Institution: Land Settlement and Mushā' Tenure in Mandate Palestine, 1921-47." Journal of the Economic and Social History of the Orient 46, no. 3: 320-54.

- 2006. The Palestinian Peasant Economy under the Mandate: A Story of Colonial Bungling. Cambridge, MA: Harvard University Press.

Nader, Laura. 1985. "Introduction." In Property, Social Structure, and Law in the Modern Middle East, edited by Ann Elizabeth Mayer, 1-24. Albany, NY: State University of New York.

Peteet, Julie. 2018. "Closure's Temporality: The Cultural Politics of Time and Waiting." South Atlantic Quarterly 117, no. 1: 43-64.

Reichman, Shalom, Yossi Katz, and Yair Paz. 1997. "The Absorptive Capacity of Palestine, 18821948." Middle Eastern Studies 33, no. 2: 338-61.

Said, Edward. 1979. The Question of Palestine. New York: Vintage. 
Sasson, Isaac, and Ronen Shamir. 2020. "The 1931 Census of Palestine and the Statistical (Un) Making of an Arab Landless Class." Middle Eastern Studies 56, no. 2: 239-56.

Schorr, David. 2014. "Water Law in British-ruled Palestine." Water History 6, no. 3: 247-63.

Seikaly, Sherene. 2016. Men of Capital: Scarcity and Economy in Mandate Palestine. Stanford, CA: Stanford University Press.

2019. "In the Matter of Time." American Historical Review 124, no. 5: 1681-88.

Shafir, Gershon. 1989. Land, Labor, and the Origins of the Israeli-Palestinian Conflict, 1882-1914. Cambridge, UK: Cambridge University Press.

Shamir, Ronen. 2013. Current Flow: The Electrification of Palestine. Stanford, CA: Stanford University Press.

2017. "Electricity and Empire in 1920s Palestine under British Rule." N.T.M. Journal of the History of Science, Technology and Medicine 24: 451-80.

Smith, Barbara Jean. 1993. The Roots of Separatism in Palestine: British Economic Policy, 1920-1929. Syracuse, NY: Syracuse University Press.

A Survey of Palestine: Prepared in December, 1945 and January, 1946 for the Information of the AngloAmerican Committee of Inquiry. 1946. Vol. 1. Palestine: Government Printer.

Trottier, Julie. 1999. Hydropolitics in the West Bank and Gaza Strip. Jerusalem: Palestinian Academic Society for the Study of International Affairs.

Tyler, Warwick. 2001. State Lands and Rural Development in Mandatory Palestine, 1920-1948. Brighton, UK: Sussex Academic Press.

Veblen, Thorstein. 1923. Absentee Ownership and Business Enterprise in Recent Times; The Case of America. New York: B. W. Huebsch.

Wolfe, Patrick. 2012. "Purchase by Other Means: The Palestine Nakba and Zionism's Conquest of Economics." Settler Colonial Studies 2, no. 1: 133-71.

Worster, Donald. 2004. Dust Bowl: The Southern Plains in the 1930s. New York: Oxford University Press. 